http://iiss.publikasiindonesia.id/

Vol. 2 No. 3 Maret 2021

P-ISSN: 2723 - 6692 dan E-ISSN: 2723 - 6595

\title{
PERAMALAN KINERJA PERBANKAN INDONESIA DENGAN ARCH-GARCH
}

\author{
Ahmad Sonjaya \\ Fakultas Ekonomi dan Bisnis UHAMKA Jakarta, Indonesia \\ Email: madson_27@yahoo.co.id
}

\begin{abstract}
Artikel info
Artikel history:

Diterima 05 Maret 2021

Diterima dalam bentuk revisi 12 Maret 2021

Diterima dalam bentuk revisi 18 Maret 2021
\end{abstract}

\section{Keywords:}

volatility; performance; arch; garch, banking
Kata kunci:

volatilitas; kinerja; arch; garch; perbankan.
Abstract: As a form of organization, banks must achieve certain goals. The successful realization of banking business objectives is management achievement. Evaluation of the performance or performance of a bank is measured because it can be used as a basis for internal and external decision making. This study aims to model and predict banking performance. This study uses monthly data from 2012 to 2020 with themethod Autoregressive Conditional Heteroscedasticity - Generalized Autoregressive Conditional Heteroscedasticity (ARCH-GARCH). The data used in this study are operational costs, operating income (BOPO), loan to deposit ratio (LDR), return on assets (ROA) and the ratio of net interest margin (NIM). The results of testing the volatility model found that all data have volatility characteristics, and the error and return on volatility in the previous period will affect several ratios. The results of the data prediction tend to be stable, although there are peaks that indicate fluctuations over a certain period.

Abstrak: Sebagai bentuk organisasi, bank harus mencapai
tujuan tertentu. Keberhasilan realisasi tujuan bisnis perbankan
adalah pencapaian manajemen. Evaluasi kinerja atau kinerja
suatu bank diukur karena dapat digunakan sebagai dasar
pengambilan keputusan internal maupun eksternal. Penelitian
ini bertujuan untuk memodelkan serta meramalkan kinerja
perbankan. Penelitian ini menggunakan data bulanan dari tahun
2012 sampai 2020 dengan metode Autoregressive Conditional
Heteroscedasticity - Generalized Autoregressive Conditional
Heteroscedasticity (ARCH-GARCH). Data yang digunakan
dalam penelitian ini adalah biaya operasional, pendapatan
operasional (BOPO), loan to deposit ratio (LDR), return on
asset (ROA) dan rasio net interest margin (NIM). Hasil
pengujian model volatilitas menemukan bahwa semua data
memiliki karakteristik volatilitas, dan kesalahan serta
pengembalian volatilitas pada periode sebelumnya akan
mempengaruhi beberapa rasio. Hasil prediksi data cenderung
stabil, meskipun terdapat puncak yang mengindikasikan
fluktuasi pada periode tertentu.


Coresponden author: Ahmad Sonjaya

Email: madson_27@yahoo.co.id

artikel dengan akses terbuka dibawah lisensi

CC BY SA

2021

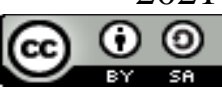

\section{Pendahuluan}

Dalam beberapa dekade terakhir, banyak revolusi telah terjadi di industri perbankan di seluruh dunia. Perubahan ini telah mempengaruhi metode bisnis dan lingkungan persaingan industri perbankan. Industri perbankan telah memberikan kontribusi terhadap struktur dan kinerja perekonomian nasional. Meski banyak partai politik dikritik karena krisis keuangan, peran industri perbankan dalam membiayai konsumen dan perusahaan komersial tetap penting. Sektor perbankan yang menguntungkan lebih mampu memberikan perlindungan terhadap guncangan negatif, sehingga membantu menstabilkan dan memperkuat sistem keuangan.

Industri perbankan tidak hanya penting untuk memperkuat proses interaksi ekonomi antar berbagai sektor pasar, tetapi juga untuk mencapai efisiensi distribusi dan operasional guna mempercepat pertumbuhan ekonomi. Di sisi lain, operasional perbankan yang kurang kondusif dan berisiko tinggi akan mempercepat ketidakstabilan keuangan dan berdampak negatif terhadap proses pertumbuhan ekonomi. Oleh karena itu, evaluasi kinerja bank telah menarik perhatian para peneliti akademis serta para manajer, pengawas bank dan pengawas pasar keuangan.

(Ahmad \& Sulaiman, 2014) Dalam perekonomian manapun, industri perbankan telah memberikan kontribusi yang sangat besar untuk meningkatkan kinerja keuangan dan membantu pemanfaatan sumber daya. Sistem perbankan yang berfungsi dengan baik memainkan peran penting dalam alokasi sumber daya, pertumbuhan ekonomi dan kinerja keuangan. Kinerja keuangan yang lebih baik dapat membantu meningkatkan investasi, sehingga menguntungkan pemegang saham dan perekonomian secara keseluruhan.

Laporan keuangan bank dirancang untuk memberikan informasi tentang status keuangan perusahaan, kinerja operasi dan arus kas. Dengan bantuan laporan keuangan, pemilik perusahaan, investor, kreditor, dan lembaga pemerintah dapat membuat keputusan pengembangan perusahaan berdasarkan informasi yang sudah ada dalam laporan keuangan. Namun, jika standar internasional untuk audit ditentukan, manajemen dapat memanipulasi catatan keuangan, sehingga mempengaruhi penyediaan informasi non-aktual.

Kinerja bank umum Indonesia menunjukkan tren yang positif, berhasil membawa pada peningkatan rata-rata penyaluran modal sebesar 8,61\%, peningkatan sumber permodalan sebesar $8,65 \%$, dan total aset $8,87 \%$. Tentunya, seiring dengan peningkatan kinerja, bank umum perlu dijaga untuk meningkatkan kepercayaan masyarakat terhadap kinerja bank umum. 


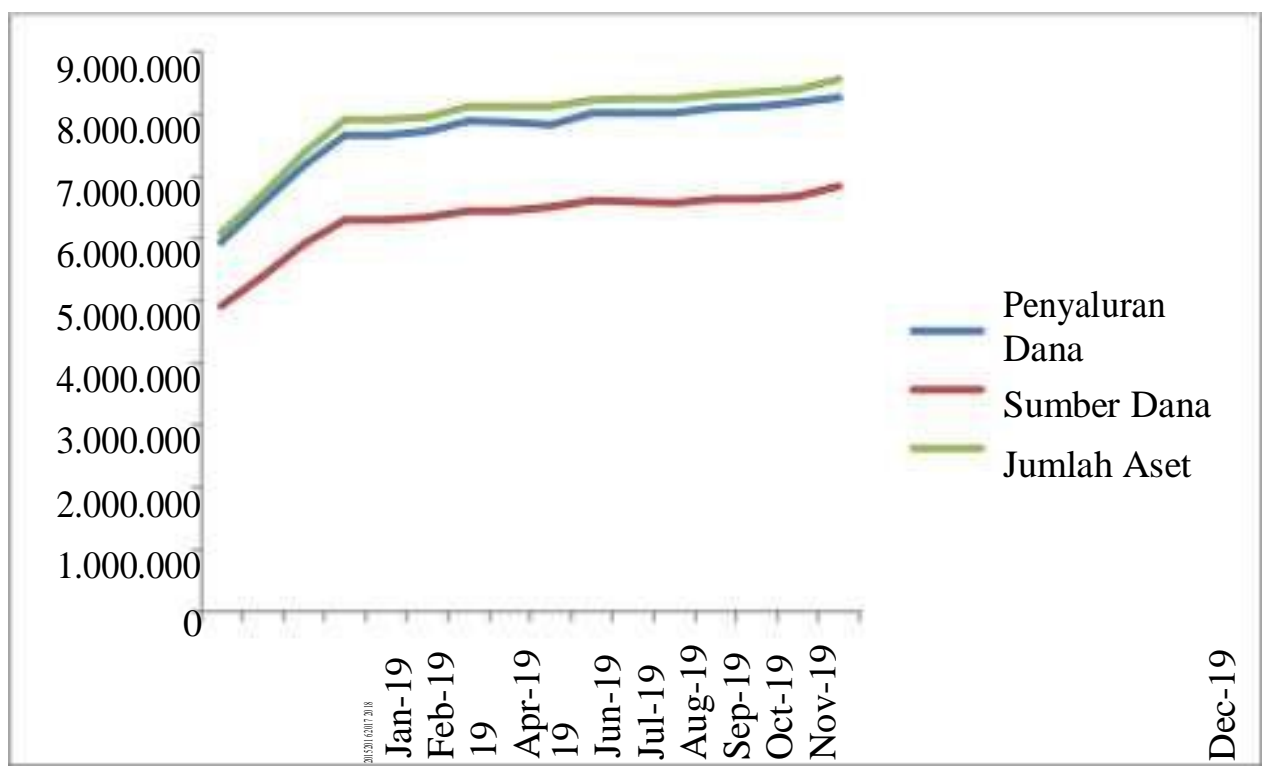

Gambar 1. Kinerja Bank Umum di Indonesia (dalam miliar)

Penelitian ini difokuskan untuk melakukan peramalan terkait dengan kinerja dari bank umum di Indonesia. Penelitian terkait dengan peramalan sudah pernah dilakukan oleh (Alizadeh et al., 2008), mengenai harga komoditas, (Henry, 2009) mengenai pengembalian saham, (Wilfling, 2009) dan (Bohl et al., 2011) mengenai pengembalian nilai tukar, (Glaser et al., 2014), (Bucko et al., 2015), mengenai volatilitas harga cryptocurrency, (Gronwald, 2014), (Dyhrberg, 2016), (Bouoiyour \& Selmi, 2016), (Ardia et al., 2019), (Eyal \& Sirer, 2014) mengenai volatilitas harga bitcoin.

Dilihat dari riset yang ada, belum ada yang pernah mengecek kinerja bank umum. Oleh karena itu, tujuan dari penelitian ini adalah untuk mengisi gap yang ada pada penelitian yang ada. Oleh karena itu, tujuan penelitian ini adalah untuk memfokuskan pada prakiraan kinerja bank umum di Indonesia. Penelitian ini memiliki kontribusi penting bagi manajer risiko dan investor dalam merumuskan strategi investasi terbaik. Mengingat penelitian ini dapat membantu pemangku kepentingan dalam menentukan pilihan kebijakan, maka perlu dilakukan juga.

Spesifikasi Autoregressive Conditional Heteroskedasticity (ARCH) awalnya diperkenalkan oleh (Engle, 1982) dan kemudian diperluas oleh (Engle, 1982) yang mengedepankan kerangka GARCH. Spesifikasi tambahan kemudian dikembangkan model eksponensial GARCH (EGARCH) dari (Nelson, 1991), model ambang GARCH (TGARCH) dari (Zakoian, 1994), model Student-t GARCH dari Bollerslev (1986), model GJRGARCH dari (Glosten et al., 1993).

Pendekatan menggunakan metode ARCH GARCH dilatarbelakangi bahwa sangat penting memprediksi kinerja perbankan pada waktu yang akan datang. Dalam studi penelitian analisis rasio dipilih sebagai salah satu metode untuk menentukan kinerja perbankan (Messod, 1999); Fanning \& Cogger, 1998; (Lenard \& Alam, 2009); (Ravisankar et al., 2011); (Dann, 2016); (Stice, 1991); (Wells, 1997). Berdasarkan (Fanning \& Cogger, 1998), (Kirkos et al., 2007), (Ravisankar et al., 2011) semakin tinggi tingkat hutang dapat menurunkan kinerja dari perbankan. Rasio selanjutnya sebagian besar digunakan dalam mengukur kinerja perbankan, yaitu rasio total utang terhadap total aset (Dalnial et al., 2014) ; (Abdou et al., 2012); (Kirkos et al., 2007) atau rasio total kewajiban terhadap total aset (Lenard \& Alam, 
2009); rasio total hutang terhadap ekuitas (Dalnial et al., 2014) ; (Kirkos et al., 2007); (Dann, 2016). Likuiditas lebih rendah dapat menjadi penghambat dalam pengembangan perbankan. Sebagian besar likuiditas diukur oleh modal kerja terhadap total aset, dan rasio aktiva lancar terhadap kewajiban lancar (Lenard \& Alam, 2009); (Ravisankar et al., 2011).

Menurut (Song et al., 2014) Bagi pengelola perbankan, motivasi untuk meningkatkan kualitas kinerja perbankan semakin meningkat. Untuk memahami apakah perusahaan terus berkembang, kebanyakan studi menggunakan rasio aktivitas, rasio laba, rasio komposisi aset, rasio penjualan terhadap total aset, rasio laba bersih terhadap penjualan, rasio laba bersih terhadap total aset, rasio aset lancar terhadap total aset terhadap melihat bank Literatur referensi kinerja menunjukkan bahwa menggunakan rasio keuangan untuk menentukan kinerja bank adalah cara sederhana untuk memprediksi kinerja bank di masa depan.

\section{Metode Penelitian}

Penelitian ini menggunakan data bulanan yang diperoleh dari Otoritas Jasa Keuangan (OJK), Bank Indonesia (BI) dan Badan Pusat Statistik (BPS). Penelitian ini mencakup bank umum tradisional. Kajian ini merupakan rangkaian waktu, dan rentang waktunya dari Januari 2012 hingga Juli 2020.

Data pendukung yang digunakan dalam penelitian ini meliputi biaya operasional, pendapatan operasional (BOPO), loan to deposit ratio (LDR), return on asset (ROA) dan tingkat bunga bersih (NIM). Data tersebut bersifat random (random) dan memiliki volatilitas yang tinggi, yang menyebabkan perubahan yang tidak konstan. Pemodelan volatilitas sangat penting untuk manajemen risiko. Oleh karena itu diperlukan model yang dapat digunakan untuk memprediksi pembiayaan heteroskedastisitas.

Biaya operasi Pendapatan operasi (BOPO) adalah profitabilitas perusahaan, yang membandingkan biaya operasi dengan pendapatan operasi. BOPO dapat melihat kemampuan perusahaan dalam mengelola biaya operasinya. Semakin besar biaya operasional, semakin buruk tingkat manajemen perusahaan.

\section{Hasil dan Pembahasan \\ Statistik Deskriptif}

Statistik deskriptif penelitian ini bertujuan untuk memberikan gambaran data dilihat dari mean, standar deviasi, maksimum, dan minimum masing-masing variabel. Nilai ratarata ROA adalah 0,026 yang mengukur kemampuan perusahaan dalam menggunakan semua sumber daya atau asetnya untuk menghasilkan laba sebesar 2,6\%. Deviasi standar ROA adalah 0,0033. Nilai standar deviasi lebih kecil dari nilai rata-rata yang berarti masih terdapat penyimpangan data dari nilai rata-rata sehingga terdapat data ekstrim yang dapat menyebabkan penyimpangan pada hasil penelitian. Nilai minimum adalah 0,019 dan nilai maksimum 0,037 . 
Tabel 1. Statistik Deskriptif

\begin{tabular}{lllll}
\hline & ROA & BOPO & NIM & LDR \\
\hline Mean & 0.026421 & 0.796537 & 0.050979 & $\mathbf{0 . 8 9 4 4 1 1}$ \\
Median & 0.025000 & 0.796300 & 0.053100 & $\mathbf{0 . 8 9 5 9 0 0}$ \\
Maximum & 0.037000 & 0.917800 & 0.060600 & $\mathbf{0 . 9 6 1 9 0 0}$ \\
Minimum & 0.019000 & 0.737400 & 0.040600 & $\mathbf{0 . 7 8 5 7 0 0}$ \\
Std. Dev. & 0.003346 & 0.036261 & 0.004573 & $\mathbf{0 . 0 3 6 6 0 0}$ \\
Skewness & 0.604419 & 0.405796 & -0.814199 & $\mathbf{- 0 . 8 2 6 5 7 4}$ \\
Observations & 103 & 103 & 103 & $\mathbf{1 0 3}$ \\
\hline
\end{tabular}

Nilai rata-rata BOPO sebesar 0,796 yang menunjukkan efisiensi kegiatan perbankan sebesar 79,6\%. Deviasi standar BOPO adalah 0,036. Nilai standar deviasi lebih kecil dari nilai rata-rata yang berarti masih terdapat deviasi data dari nilai rata-rata sehingga beberapa data yang ekstrim akan menyebabkan hasil penelitian menjadi bias. Nilai terendah sebesar 0,737 dan nilai tertinggi 0,917 .

Nilai rata-rata NIM adalah 0,05 yang mengukur kemampuan manajemen bank dalam mengelola aset pendapatannya untuk menghasilkan pendapatan bunga bersih sebesar 5\%. Nilai standar deviasi NIM adalah 0,004. Nilai standar deviasi lebih kecil dari nilai rata-rata yang berarti masih terdapat penyimpangan data dari nilai rata-rata sehingga terdapat data ekstrim yang dapat menyebabkan penyimpangan pada hasil penelitian. Nilai minimum adalah 0,04 dan nilai maksimum 0,06 .

Nilai rata-rata NIM adalah 0,05 yang mengukur kemampuan manajemen bank dalam mengelola aset pendapatannya untuk menghasilkan pendapatan bunga bersih sebesar 5\%. Simpangan baku NIM adalah 0,004. Nilai standar deviasi lebih kecil dari nilai rata-rata yang artinya masih terdapat penyimpangan data dari nilai rata-rata, sehingga terdapat data ekstrim yang dapat mengakibatkan penyimpangan pada hasil penelitian. Nilai minimum adalah 0,04 dan nilai maksimum 0,06.

\section{Pergerakan Kinerja Perbankan}

Gambar 2 merupakan pergerakan nilai objek observasi yang terdiri dari ROA, BOPO, NIM dan LDR. Berdasarkan hal tersebut terlihat bahwa setiap variabel yang menjadi target pengamatan memiliki volatilitas yang tinggi, seperti fluktuasi nilai setiap rasio observasi atau jarak antar fluktuasi yang besar. 


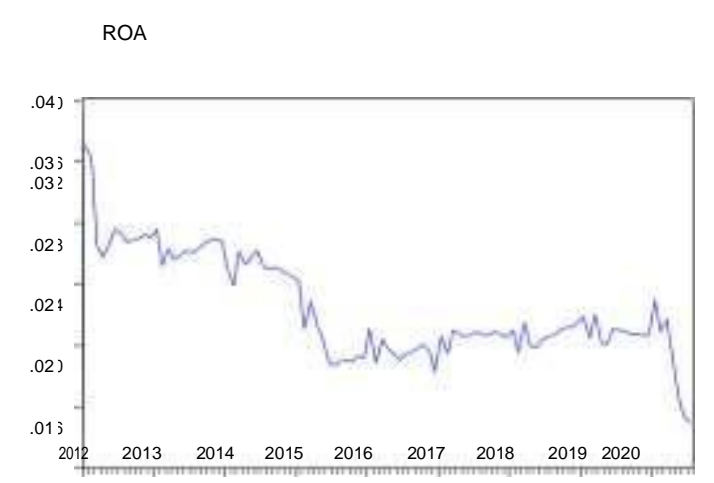

NIM

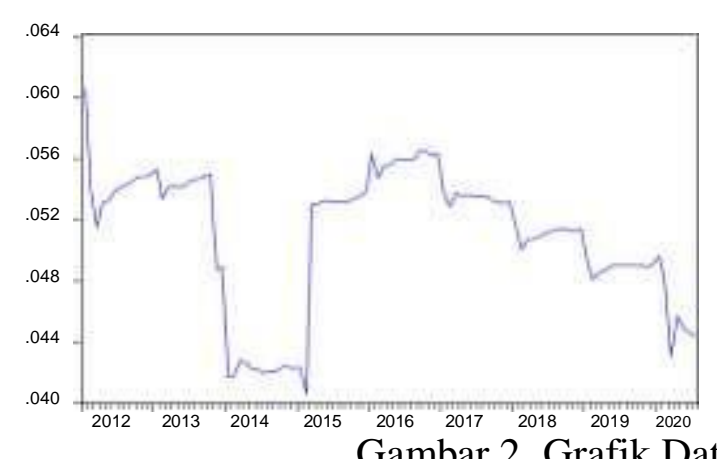

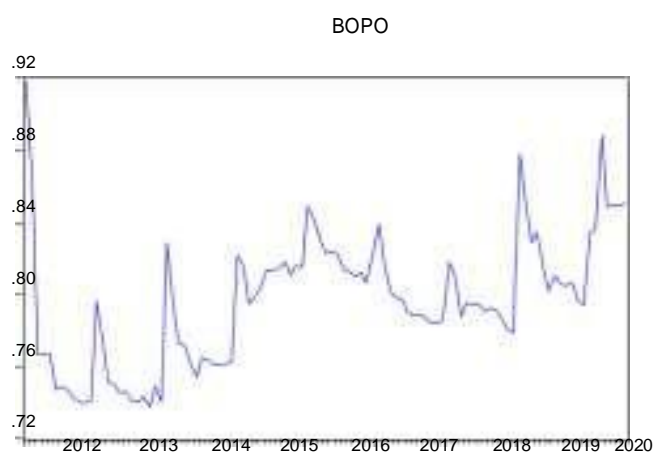

LDR

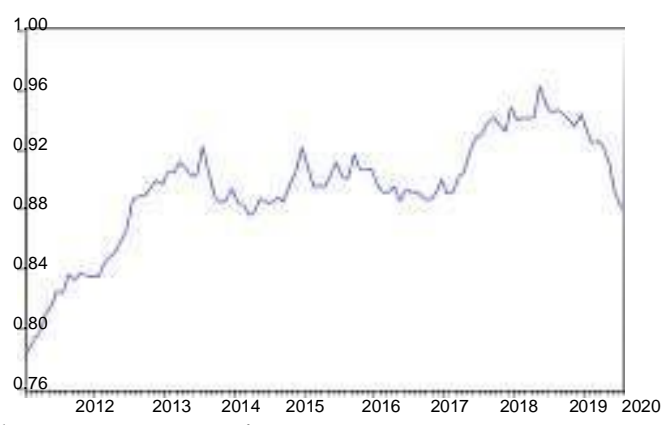

\section{Pembahasan}

Langkah pertama adalah menguji stasioneritas data, tujuannya adalah untuk melihat apakah mean, varians dan kovarian dari data tersebut konstan. Uji stasioneritas merupakan salah satu prasyarat penting dalam model ekonometri data deret waktu. Sebelum pemodelan, perlu dipastikan kestabilan data dalam penelitian ini. Studi ini menggunakan uji Dickey-Fuller yang disempurnakan untuk menguji apakah datanya stabil.

Dengan menggunakan hasil uji Enhanced Dickey-Fuller terlihat bahwa nilai probabilitas variabel BOPO dan LDR pada level ini * lebih kecil dari 0,05 sedangkan ROA dan NIM berada pada level selisih. Hasil pengujian ini menunjukkan bahwa data tetap berada pada level selisih dan level selisih.

Table 2. Uji Akar Unit Augmented Dickey-Fuller

\begin{tabular}{|c|c|c|c|c|c|c|}
\hline & \multicolumn{3}{|c|}{ Level } & \multicolumn{3}{|c|}{ Difference } \\
\hline Variabel & ADF Statistic & $\begin{array}{l}\mathrm{t}- \\
\text { Statistic } \\
5 \%\end{array}$ & $\begin{array}{l}\text { Prob } \\
*\end{array}$ & ADF Statistic & $\begin{array}{c}\text { t-Statistic } \\
5 \%\end{array}$ & Prob* \\
\hline BOPO & -4.228783 & -2.89 & $\begin{array}{l}0.00 \\
1\end{array}$ & -3.9356 & -2.89 & 0.0027 \\
\hline LDR & -3.197548 & -2.89 & $\begin{array}{l}0.02 \\
3\end{array}$ & -9.1705 & -2.89 & 0.0000 \\
\hline ROA & -2.358027 & -2.89 & $\begin{array}{l}0.15 \\
6\end{array}$ & -12.548 & -2.89 & 0.0001 \\
\hline NIM & -2.455279 & -2.89 & $\begin{array}{l}0.12 \\
9\end{array}$ & -11.288 & -2.89 & 0.0000 \\
\hline
\end{tabular}

Setelah memastikan bahwa datanya stabil maka langkah selanjutnya adalah menentukan model ARIMA terbaik. Tunjukkan model ARIMA (p, d, q) terbaik dengan 
overfitting, dan gunakan kondisi dengan nilai Akaike Information Criterion (AIC) terkecil dan nilai prob * dari setiap variabel yang valid untuk diuji. Dari uji heteroskedastisitas dengan menggunakan uji ARCH-LM, data mengandung heteroskedastisitas, karena nilai probabilitas statistik $\mathrm{F}$ lebih rendah dari nilai signifikansi 0,05, sehingga uji model ARCH-GARCH dapat digunakan untuk melanjutkan data.

Table 3. Overfitting model ARIMA $(p, d, q)$

\begin{tabular}{cccc}
\hline Variabel & ARIMA $(\boldsymbol{p}, \boldsymbol{d}, \boldsymbol{q})$ & AIC & ARCH-LM \\
\hline ROA & $(2,0,2)$ & -9.625408 & 0.0000 \\
BOPO & $(5,0,5)$ & -3.90873 & 0.0000 \\
NIM & $(3,1,4)$ & -8.741614 & 0.0000 \\
LDR & $(4,0,3)$ & -5.384261 & 0.0000 \\
\hline
\end{tabular}

Tabel 3 menunjukkan hasil pemilihan model GARCH terbaik untuk masing-masing variabel. Model terbaik dipilih berdasarkan nilai AIC terkecil dan nilai koefisien efektif.

$$
\mathrm{ROA} \mathrm{h}=8.65 \mathrm{E}-07+0.8171-12
$$

Informasi yang diberikan oleh model ROA menunjukkan bahwa tingkat risiko ROA dipengaruhi oleh besarnya nilai sisa pengembalian hari sebelumnya.

$$
\mathrm{BOPO} \mathrm{h}=8.66 \mathrm{E}-05+1.7576-12-0.1392 \mathrm{~h}-1
$$

Model BOPO memberikan informasi bahwa tingkat resiko BOPO dipengaruhi oleh besarnya nilai sisaan return satu hari sebelumnya dan besarnya simpangan baku return dari rataannya untuk satu hari sebelumnya.

$$
\mathrm{NIM} \mathrm{h}=1.11 \mathrm{E}-06+0.8723-12-0.0110 \mathrm{~h}-1
$$

Informasi yang diberikan oleh model NIM menunjukkan bahwa tingkat risiko NIM dipengaruhi oleh besar kecilnya nilai pengembalian sisa hari sebelumnya dan standar deviasi dari rata-rata tingkat pengembalian hari sebelumnya.

LDR $\mathrm{h}=7.69 \mathrm{E}-05+0.5754-12$

Informasi yang diberikan oleh model LDR menunjukkan bahwa tingkat risiko LDR dipengaruhi oleh nilai sisa pendapatan hari sebelumnya.

Table 4. Overfitting Model GARCH $(p, q)$

\begin{tabular}{|c|c|c|c|c|c|}
\hline & $(\mathrm{p}, \mathrm{q})$ & $\mathrm{C}$ & ARCH $(\mathrm{t}-1)$ & GARCH (t-1) & AIC \\
\hline ROA & $(1,0)$ & $8.65 \mathrm{E}-07^{*}$ & $0.8171^{*}$ & & -10.2816 \\
\hline BOPO & $(1,1)$ & $8.66 \mathrm{E}-05^{*}$ & $1.7576^{*}$ & $-0.1392^{*}$ & -4.48714 \\
\hline NIM & $(1,1)$ & $1.11 \mathrm{E}-06^{*}$ & $0.8723^{*}$ & $-0.0110^{*}$ & -5.16532 \\
\hline LDR & $(1,0)$ & $7.69 \mathrm{E}-05^{*}$ & $0.5754^{*}$ & & -5.96645 \\
\hline
\end{tabular}

*signifikan5 persen

Langkah selanjutnya adalah menggunakan uji ARCH-LM untuk menguji keakuratan model untuk menangkap kesalahan. Uji ARCH-LM dirancang untuk menguji apakah masih terdapat efek heteroskedastisitas palsu. Hasil pengujian ARCH-LM menemukan bahwa setelah melakukan pemodelan $\mathrm{GARCH}$, data tidak mengandung efek heteroskedastisitas. Dengan melihat hasil uji normalitas nilai kurtosis, distribusi error tidak akan berkembang secara normal. 
Langkah terakhir adalah memprediksi setiap variabel dalam penelitian. Diperkirakan akan dilakukan sebulan sekali mulai tahun 2021 hingga akhir tahun 2024. Data untuk setiap variabel tersedia dari Januari 2012 hingga Juni 2020. Perkiraan data dari Juli 2020 hingga Desember 2024.

Tabel 5. Diagnostic Model

\begin{tabular}{|c|c|c|}
\hline Variabel & Heteroskedastisitas & Normalitas \\
\hline ROA & 0.6371 & -0.687307 \\
\hline BOPO & 0.3848 & 0.508468 \\
\hline NIM & 0.8492 & -0.783746 \\
\hline LDR & 0.5242 & 0.3228 \\
\hline
\end{tabular}

Dapat dilihat dari Tabel 5 bahwa data yang tersedia dan data prediksi variabel BOPO mengalami fluktuasi.Nilai data prediksi variabel BOPO tertinggi pada bulan Agustus 2020 yaitu sebesar 85,42\% dan nilai terendah pada bulan Mei 2022 yaitu sebesar 76,85\%. . Diperkirakan titik terendah variabel LDR pada Agustus 2020 sebesar 79,88\%, dan titik tertinggi pada Juni 2024 sebesar 92,56\%.

BOPO digunakan untuk mengendalikan biaya operasi dan pendapatan operasi. Bisnis perbankan BOPO mengalami volatilitas dan tumbuh di akhir tahun. Pasalnya, restrukturisasi kredit menghasilkan cadangan yang lebih tinggi akibat dampak pandemi. Pandemi tersebut menyebabkan rasio BOPO terus meningkat yang memberikan tekanan pada pendapatan bank, terutama pendapatan bunga dari restrukturisasi kredit. Oleh karena itu, bank biasanya menyiapkan cadangan kerugian penurunan nilai (CKPN) yang cukup untuk menambah biaya operasional.

Bank ingin menaikkan biaya operasional, sehingga bekerja keras untuk meningkatkan efisiensinya. Upaya tersebut dilakukan dengan terus memangkas beban bunga dan fokus pada penghimpunan dana murah (giro dan tabungan / CASA). Selain meningkatkan efisiensi pembayaran bunga dan memperhatikan CASA, perbankan juga perlu mengoptimalkan efisiensi layanan digital dan biaya operasional bank.

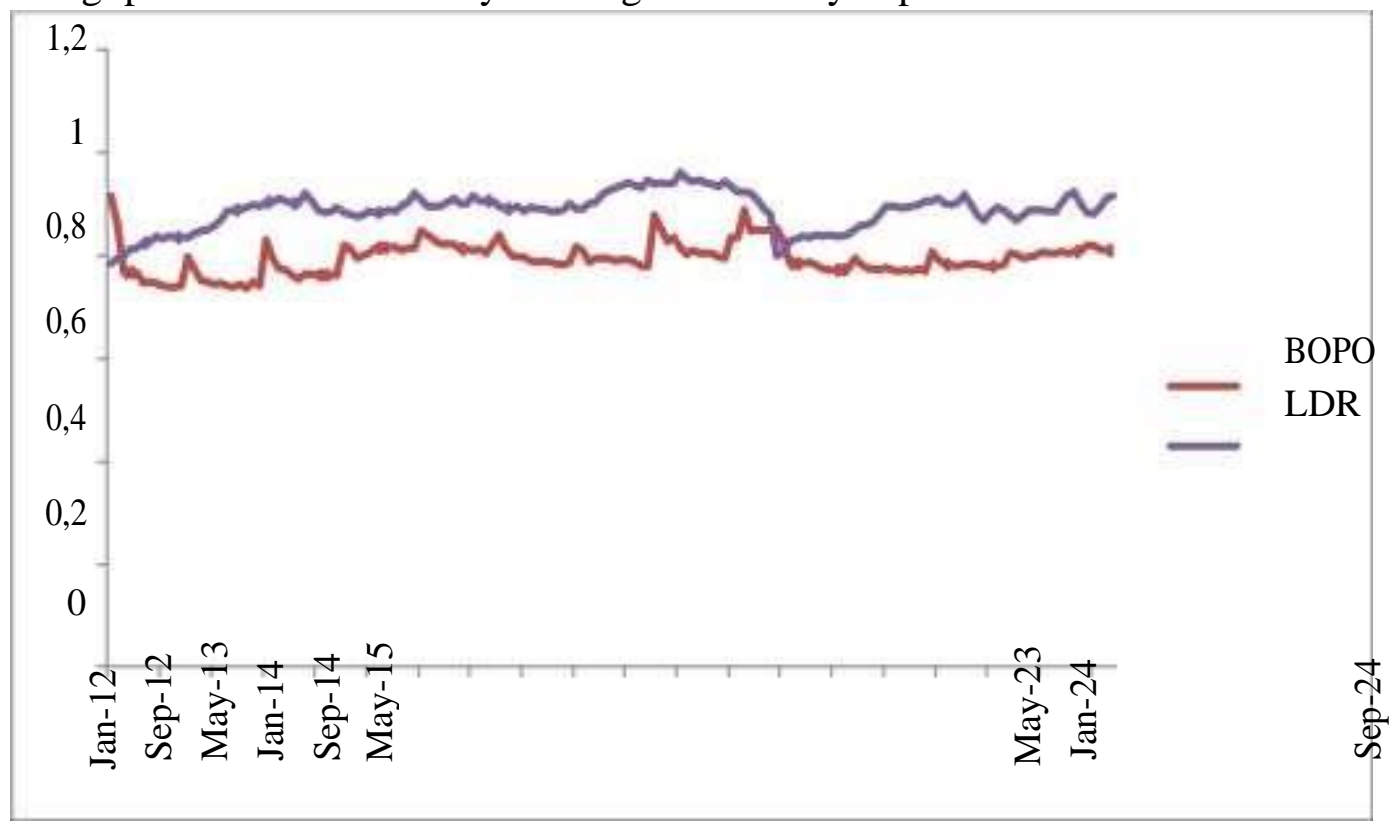

Gambar 3. Peramalan BOPO dan LDR 
Secara umum, bank perlu menjaga rasio BOPO pada level aman di bawah $85 \%$. Langkah efisiensi dapat dilakukan dengan meningkatkan penggunaan teknologi dalam proses bisnis. Teknologi utama tersebut akan digunakan untuk mendorong pinjaman bank dengan meningkatkan pendapatan bunga.

Secara umum, bank perlu menjaga rasio BOPO pada tingkat yang aman di bawah 85\%. Langkah efisiensi dapat dilakukan dengan meningkatkan penggunaan teknologi dalam proses bisnis. Teknologi utama tersebut akan digunakan untuk mendorong pinjaman bank dengan meningkatkan pendapatan bunga.

Peningkatan LDR tentunya didorong oleh pertumbuhan kredit yang tinggi. Likuiditas tinggi terkait dengan pinjaman kecil. Masalah utama bisnis perbankan bukan hanya permodalan dan pertumbuhan ekonomi, tetapi juga likuiditas. Tantangan ini dapat diatasi dengan membatasi pertumbuhan kredit atau menaikkan suku bunga tabungan untuk meningkatkan dana tabungan.

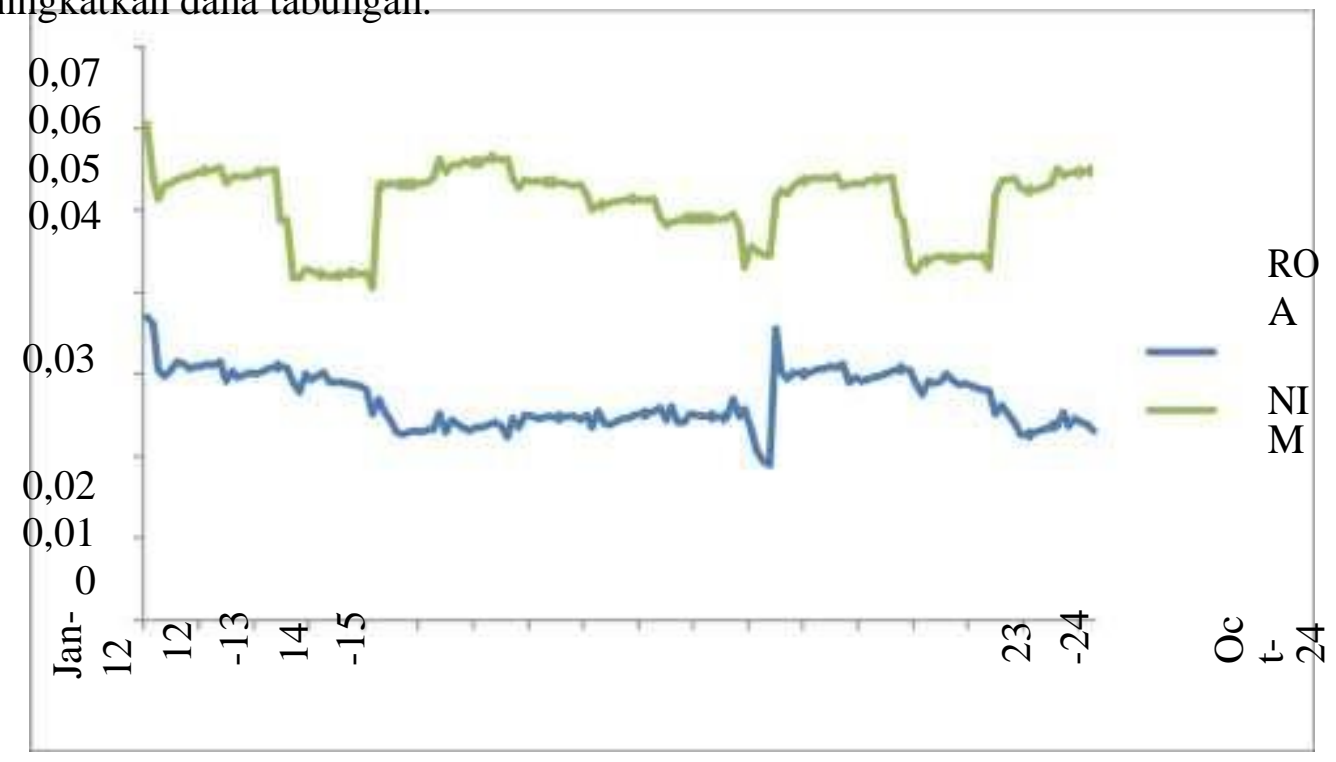

Gambar 4. Peramalan ROA dan NIM

Kenaikan suku bunga acuan Bank Indonesia (BI) akan direspon perbankan dengan menaikkan suku bunga kredit dan deposito. Namun, melakukan penyesuaian ini akan mempertimbangkan kondisi likuiditas dan pasar bank. Selain itu, bank akan memperhatikan kondisi pasar untuk menjaga daya saing dan menjaga profitabilitas dan kualitas kredit. Pertumbuhan dana akan dikelola secara optimal untuk mendukung pertumbuhan kredit, dengan rasio pinjaman terhadap tabungan (LDR) antara 90\% hingga $91 \%$.

Namun bank harus lebih konservatif dalam menjaga likuiditas bank. Kualitas kredit menjadi prioritas utama bisnis perbankan.Selain transaksi perbankan, perbankan juga perlu menjaga likuiditas. Dampak kenaikan suku bunga simpanan dan kredit akan mempengaruhi pola pertumbuhan dana pihak ketiga (DPK) dan kredit sehingga mempengaruhi rasio pinjaman terhadap simpanan dalam jangka panjang.

ROA digunakan untuk mengukur laba atas investasi yang diperoleh perusahaan dengan menggunakan semua dana (aset) yang dimilikinya. Dalam prediksi yang dibuat, profitabilitas bank diperkirakan akan mengalami masa penurunan laba. Hal tersebut tercermin dari penurunan return on asset (ROA) bank pada tahun 2023. 
Kemampuan bank untuk menghasilkan keuntungan pada tahun 2023 tidak akan secepat tahun 2022. Selain rendahnya permintaan pinjaman baru, hal ini juga karena bank harus mematuhi banyak regulasi dan berakibat pada berkurangnya keuntungan. Alasan penurunan tersebut lebih karena penurunan laba sebelum pajak. Penurunan laba atas aset tersebut disebabkan oleh besarnya penyisihan kerugian penurunan nilai. Bank perlu fokus pada efisiensi biaya modal dengan merestrukturisasi simpanan berbiaya tinggi dan berinvestasi pada dana murah, sekaligus fokus pada peningkatan kualitas kredit untuk meningkatkan pendapatan bunga.

Suku bunga bersih (NIM) digunakan untuk mengukur kemampuan manajemen bank dalam mengelola aset pendapatannya untuk menghasilkan pendapatan bunga bersih. Kenaikan atau penurunan NIM mengikuti tren kenaikan suku bunga dan persaingan yang semakin ketat. Berdasarkan hasil prakiraan, suku bunga bersih bank mengalami masa pasang surut. Selama periode ini, alasan penurunan suku bunga bersih adalah suku bunga kredit dan biaya modal, yang juga merupakan biaya modal. Jika cost of fund meningkat, hal tersebut menandakan bahwa likuiditas pasar sedang mengalami pengetatan yang akan menyebabkan bank menaikkan suku bunga pinjaman untuk jangka waktu tertentu.

Akibatnya, dampak pembelian kredit lambat laun akan berkurang karena kemampuan membeli atau membayar masyarakat menurun, atau calon debitur mungkin memilih menunggu dan meminjam ke bank. Namun, bank tidak perlu khawatir dengan pengurangan kapasitas pinjaman publik. Pasalnya, bank sentral akan mengeluarkan beberapa langkah mitigasi, seperti melonggarkan kebijakan loan value assesment (LTV) dan melonggarkan kebijakan penghitungan aset tertimbang menurut risiko (ATMR). Caracara ini sangat berguna bagi bank untuk menarik calon peminjam dengan lebih leluasa selama periode kenaikan suku bunga pinjaman.

\section{Kesimpulan}

Penelitian ini dilakukan untuk menguji karakteristik industri perbankan Indonesia atau model volatilitas pada periode observasi dan data prakiraan kinerja. Sebanyak empat data yang digunakan yaitu return on asset (ROA), pendapatan operasional terhadap pendapatan operasional (BOPO), suku bunga bersih (NIM) dan loan to deposit ratio (LDR).

Hasil pengujian model volatilitas menemukan bahwa semua data memiliki karakteristik volatilitas, dan penggunaan model GARCH ditemukan bahwa kesalahan sebelumnya dan volatilitas tingkat pengembalian mempengaruhi beberapa rasio. Rasio ROA dan LDR hanya dipengaruhi oleh nilai sisa atau error pada periode sebelumnya. Dari pengujian ARCH-LM terakhir didapatkan bahwa semua model dalam keadaan baik karena heteroskedastisitasnya telah hilang.

Sementara itu, hasil prakiraan menunjukkan bahwa meskipun beberapa puncak berfluktuasi dalam kurun waktu tertentu, datanya cenderung stabil. Berdasarkan hasil prediksi dengan menggunakan model ARIMA dapat diketahui bahwa dalam 60 bulan ke depan ratarata rasio LDR memiliki nilai deviasi atau volatilitas terbesar, dan rata-rata standar deviasi sebesar 0,222794. Sementara itu, dapat dilihat dari prediksi yang dilakukan dengan menggunakan model ARCH-GARCH bahwa dalam 60 bulan ke depan rata-rata rasio LDR memiliki nilai deviasi atau volatilitas terbesar, dengan rata-rata standar deviasi 0,0289236. 


\section{Bibliografi}

Abdou, H. A., Kuzmic, A., Pointon, J., \& Lister, R. J. (2012). Determinants of capital structure in the UK retail industry: A comparison of multiple regression and generalized regression neural network. Intelligent Systems in Accounting, Finance and Management, $19(3), 151-169$.

Ahmad, F. M. A. A. R., \& Sulaiman, A. (2014). International Journal of Islamic and Middle Eastern Finance and Management. Management, 7(2), 161-169.

Alizadeh, A. H., Nomikos, N. K., \& Pouliasis, P. K. (2008). A Markov regime switching approach for hedging energy commodities. Journal of Banking \& Finance, 32(9), 19701983.

Ardia, D., Bluteau, K., \& Rüede, M. (2019). Regime changes in Bitcoin GARCH volatility dynamics. Finance Research Letters, 29, 266-271.

Bohl, M. T., Salm, C. A., \& Wilfling, B. (2011). Do individual index futures investors destabilize the underlying spot market? Journal of Futures Markets, 31(1), 81-101.

Bouoiyour, J., \& Selmi, R. (2016). Bitcoin: A beginning of a new phase. Economics Bulletin, 36(3), 1430-1440.

Bucko, J., Palová, D., \& Vejacka, M. (2015). Security and trust in cryptocurrencies. Central European Conference in Finance and Economics, 14-24.

Dalnial, H., Kamaluddin, A., Sanusi, Z. M., \& Khairuddin, K. S. (2014). Accountability in financial reporting: detecting fraudulent firms. Procedia-Social and Behavioral Sciences, 145, 61-69.

Dann, R. (2016). Developing understanding of pupil feedback using Habermas' notion of communicative action. Assessment in Education: Principles, Policy \& Practice, 23(3), $396-414$.

Dyhrberg, A. H. (2016). Bitcoin, gold and the dollar-A GARCH volatility analysis. Finance Res. Lett. 16, 85-92 (2016).

Engle, R. F. (1982). Autoregressive conditional heteroscedasticity with estimates of the variance of United Kingdom inflation. Econometrica: Journal of the Econometric Society, 987-1007.

Eyal, I., \& Sirer, E. G. (2014). Majority is not enough: Bitcoin mining is vulnerable. International Conference on Financial Cryptography and Data Security, 436-454.

Fanning, K. M., \& Cogger, K. O. (1998). Neural network detection of management fraud using published financial data. Intelligent Systems in Accounting, Finance \& Management, 7(1), 21-41.

Glaser, F., Zimmermann, K., Haferkorn, M., Weber, M. C., \& Siering, M. (2014). Bitcoinasset or currency? revealing users' hidden intentions. Revealing Users' Hidden 
Ahmad Sonjaya

Intentions (April 15, 2014). ECIS.

Glosten, L. R., Jagannathan, R., \& Runkle, D. (1993). On the relationship between GARCH and symmetric stable process: Finding the source of fat tails in data. Journal of Finance, 48(5), 1779-1802.

Gronwald, M. (2014). The economics of bitcoins--market characteristics and price jumps.

Henry, O. T. (2009). Regime switching in the relationship between equity returns and shortterm interest rates in the UK. Journal of Banking \& Finance, 33(2), 405-414.

Kirkos, E., Spathis, C., \& Manolopoulos, Y. (2007). Data mining techniques for the detection of fraudulent financial statements. Expert Systems with Applications, 32(4), 995-1003.

Lenard, M. J., \& Alam, P. (2009). An historical perspective on fraud detection: From bankruptcy models to most effective indicators of fraud in recent incidents. Journal of Forensic \& Investigative Accounting, 1(1), 1-27.

Messod, B. D. (1999). The detection of earnings manipulation. Financial Analyst Journal, $5(55), 22-36$.

Nelson, D. B. (1991). Conditional heteroskedasticity in asset returns: A new approach. Econometrica: Journal of the Econometric Society, 347-370.

Ravisankar, P., Ravi, V., Rao, G. R., \& Bose, I. (2011). Detection of financial statement fraud and feature selection using data mining techniques. Decision Support Systems, 50(2), 491-500.

Song, X., Hu, Z., Du, J., \& Sheng, Z. (2014). Application of machine learning methods to risk assessment of financial statement fraud: evidence from China. Journal of Forecasting, 33(8), 611-626.

Stice, J. D. (1991). Using financial and market information to identify pre-engagement factors associated with lawsuits against auditors. Accounting Review, 516-533.

Wells, J. T. (1997). Occupational fraud and abuse. Austin, TX. Obsidian Publ. Co., Inc.

Wilfling, B. (2009). Volatility regime-switching in European exchange rates prior to monetary unification. Journal of International Money and Finance, 28(2), 240-270.

Zakoian, J. (1994). M+ 1994! Threshold heteroskedastic functions+. Journal of Economic Dynamics and Control, 18, 931-955. 